\title{
A new method by correlation to forecast the optimal time of spore- prints production and collection on sporocarps of Ganoderma resinaceum Boud. (Basidiomycota) on natural substrate
}

\author{
Kengni Ayissi $\mathrm{MB}^{1}$, Mossebo $\mathrm{DC}^{1^{*}}$, Machouart $\mathrm{MC}^{3}$, Kansci $\mathrm{G}^{2}$, Tsigaing \\ $T_{F}{ }^{1}$, Dogang $L R^{1}$, Metsebing $B^{1}$ and Djifack $N^{1}$
}

\author{
${ }^{1}$ University of Yaoundé 1, Mycological Laboratory, B.P. 1456 Yaoundé, Cameroon \\ ${ }^{2}$ University of Yaoundé 1, Laboratory of Biochemistry, Nutrition and Food Technology, B.P. 812, Yaoundé, Cameroon \\ ${ }^{3}$ Laboratoire Stress Immunité Pathogène - EA 7300 - Université de Lorraine, 9 avenue de la forêt de Have, \\ 54511 Vandoeuvre les Nancy, France
}

Kengni Ayissi MB, Mossebo DC, Machouart M, Kansci G, Tsigaing TF, Dogang LR, Metsebing BP, Difack NM 2014 - A new method by correlation to forecast the optimal time of spore-prints production and collection on sporocarps of Ganoderma resinaceum Boud. (Basidiomycota) on natural substrate. Mycosphere 5(6), 758-767, Doi 10.5943/mycosphere/5/6/6

\begin{abstract}
Spores features of most fungal species are of prime importance in the process of their identification. These spores could also be used for numerous other studies including fungal genetics, reproduction and molecular biology. Studies involving single spore cultures are numerous in various domains of mycology and these isolated spores could be obtained at best only from spore-prints. These spore prints are most often produced by sporocarps of most Agaricales on field and also in the laboratory after collection. In contrary, Ganoderma in general including G. resinaceum produce spore-prints only on field and for a limited period of time not covering all their life span. These spore-prints could therefore be collected only on the field during a well defined period. The correlation equation $\mathrm{Y}=\mathrm{a}+\mathrm{bX}$ between size of sporocarps and time of growth now renders possible the forecast of the period of spore-prints production by sporocarps of G. resinaceum on natural substrate, thereby enabling collection of these spores at the best time on field for various mycological investigations.
\end{abstract}

Key words - basidiocarp size - correlation equation - field data - Ganodermataceae - life span spore collection - time of growth

\section{Introduction}

The genus Ganoderma Karst with over 250 species (Ryvarden 1992, Chang \& Buswell 1999 ) is a cosmopolitan genus recorded worldwide as well in tropical as in temperate climates. It belongs to the family Ganodermataceae with as key characters the shape and size of basidiospores and the texture of the pileus (Ryvarden 2000). Several species are found in tropical Africa (Bresadola 1890; Steyaert 1962, 1967, 1980; Futardo 1965, 1967; Zoberi 1972; Ryvarden \& Johansen 1980; Ryvarden 1992; Hjortstam et al. 1993; Moncalvo \& Ryvarden 1997; Roberts \& Ryvarden 2006; Kinge 2012; Mossebo et al. 2014a; Mossebo \& Kengni Ayissi 2014b) and numerous studies have so far been carried out in this genus due to its importance in various 
scientific domains such as agriculture, forestry and medicine.

The taxonomy of Ganoderma as well as that of other groups of Macromycetes is primarily based on macro- and micromorphological characters of sporocarps, sometimes completed by molecular phylogeny. The micro-morphological features in particular refer among others to the morphology, size and ornamentations of spores and cuticle cells according to Steyaert (1972) and Ryvarden (2000) who warranted that "the two most important characters in the genus are the shape and size of basidiospores and cuticle cells". Also, Ling-Chie Wong et al. (2012) later on added that "spore length can be used to distinguish Ganoderma spp.". However and contrary to numerous other Macromycetes of other genera including most Agaricales of which the sporocarp pileus is known for most species to be able to keep on producing spores days after collection, sporocarps of Ganoderma in general produce spore-prints only on their natural substrate (Figs 1C-D) and for a limited time period most often ranging from maturity to the moment just preceding the beginning of senescence. Also, according to our field and lab monitoring, sporocarps cease producing sporeprints immediately after collection (Fig. 1F) from substrate, what renders absolutely necessary the collection of these spore-prints rather on living sporocarps still on substrate (Figs 1C-D) for taxonomic purposes (spore-print and spore colour(s), size, morphology, ornamentations), or more specific studies needing a great number of isolated individual spores such as genetics of reproduction, polarity in sexual reproduction by crossings of mycelium (Adaskaveg \& Giltbertson 1986, Mossebo 1995, Mossebo et al. 1998) from single - or multispores cultures.

However such quantities of single- or multispores are hardly found in basidiocarps tissues (pores or tubes section) during morphological investigations and can only be obtained from sporeprints, which as said earlier and as far as Ganoderma in general are concerned, are produced only by living sporocarps still on substrate (Figs 1C-D) and just for a limited period of time in their life span.

The correlation equation $\mathrm{Y}=\mathrm{a}+\mathrm{bX}$ [where $\mathrm{Y}$ represents the size (length $(\mathrm{L})$ or width ( 1 ) of sporocarp growing on its natural substrate) and $\mathrm{X}$ is the time in days of growth ] worked out by the authors for the first time as far as $G$. resinaceum is concerned, henceforth enables to determine the approximate time of growth and remaining life span of a young basidiocarp in active growth (Fig. 1E), as well as the approximate best time period for collection of spore-prints (Figs 1C-D) on the field for various mycological investigations.

\section{Materials \& Methods}

\section{Taxonomy and identification}

Specimens of Ganoderma monitored on the field were first thoroughly scrutinized in taxonomy in order to determine whether they actually belong to Ganoderma resinaceum which is the more widespread and readily available species in the study area. Their macro- and micromorphological features were first described according to various protocols used for Polyporales description (Ryvarden \& Johansen 1980; Mossebo \& Ryvarden 1997, 2003; Mossebo 2005; Mossebo et al. 2007) and more specific protocols for Ganoderma (Nŭnez \& Ryvarden 2000; Ryvarden 2000, 2004; Kinge \& Mih 2011; Kinge 2012; Mossebo et al. 2014a; Mossebo \& Kengni Ayissi 2014b). These features were thereafter compared to those of existing taxa of Ganoderma described in the most reliable taxonomic studies cited above in order to determine whether the specimen actually belongs to $G$. resinaceum. Other specimens were sent to Ryvarden (personal communication) at the University of Oslo in Norway for cross-checking our preliminary identifications.

\section{Correlation between time and growth parameters of sporocarps of $G$. resinaceum in vivo}

Some growth parameters of $G$. resinaceum such as the length and width of 6 different sporocarps as 6 replicates growing on tree stumps and trunks (Figs 1A-B-C-D-E) at 6 different sites (Table 3) in Cameroon were monitored on a regular basis. G. resinaceum being the more widespread and readily available species in the study area, the 6 sporocarps were selected among 

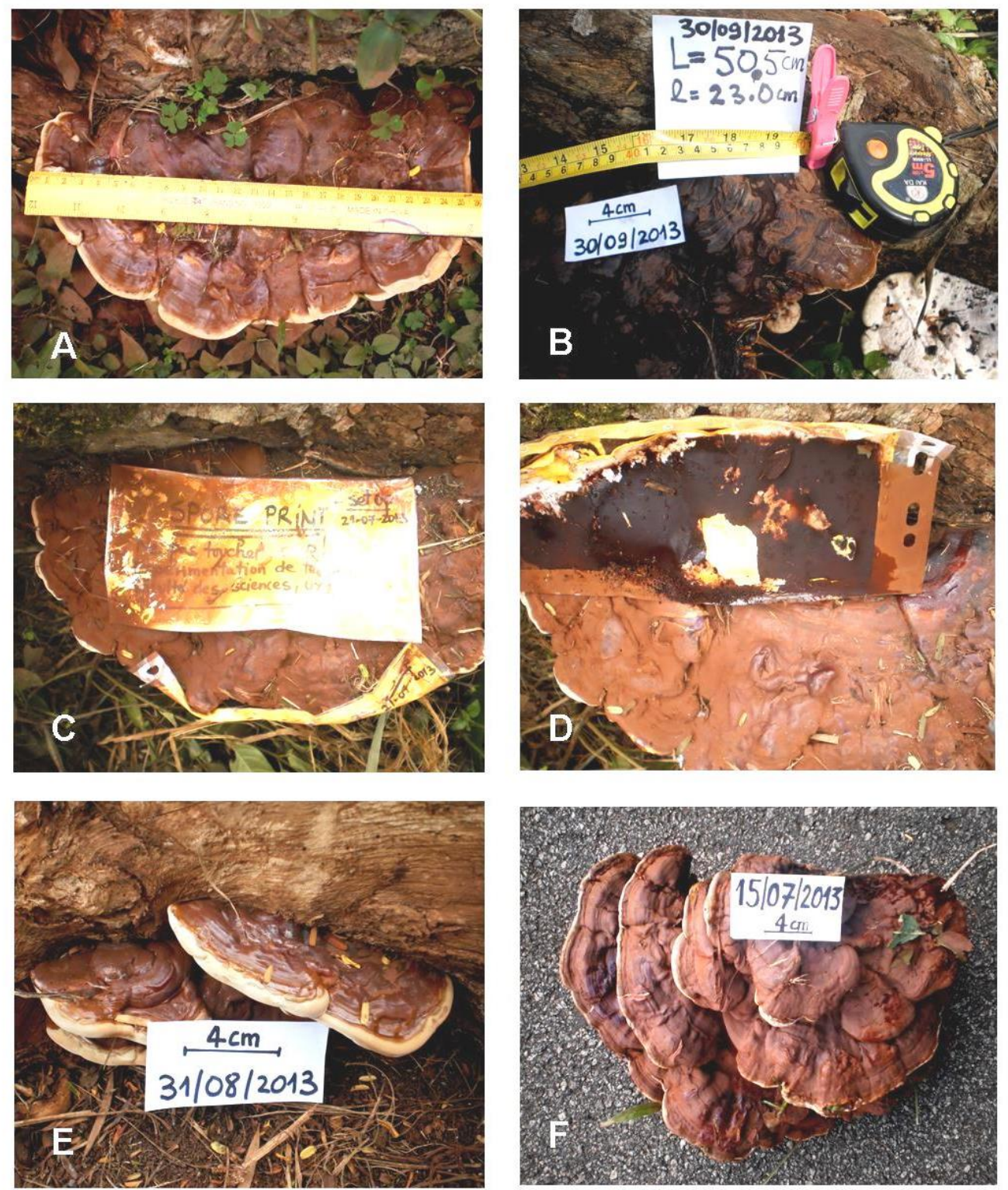

Fig. 1 - Monitoring growth and spore-print production of Ganoderma resinaceum on natural substrate (mostly dead wood). A-B Measurements of length and width of sporocarp. C-D Sporeprint produced by sporocarp on natural substrate. E Young sporocarps in active growth. F Sporocarp cease producing spore-print once collected from substrate. Scale bars as shown on the figures.

other criteria, that they should be of equal size or nearly so at the launching of the study. Also, a sporocarp was selected only when there was no other fungal species on the same substrate in order to avoid possible negative effects of eventual mycoparasitism or fungal competition. Length and width of sporocarps were measured (Figs 1A-B) every 2 weeks over more than 250 days (Table 1 $\& 2$ ) and the measurements correlated with time in days of growth, in order to compute for the first time since the first description (Boudier 1889) of $G$. resinaceum, the correlation equation $\mathrm{Y}=\mathrm{a}+\mathrm{bX}$ (Mc. Donald 2014; Parker 1991) between length of sporocarp and time of growth on the one hand, and width and time of growth on the other hand. The natural production of spores as spore-prints was equally closely monitored by attaching with tailor needles pieces of contrast paper (Figs 1C-D) on the upper and lower sides of the 6 basidiocarps (6 replicates) at different sites (Table 3) in Cameroon in order to determine the time of growth corresponding to the beginning and end of production of spore-prints on natural substrate on the field. The spore-print colour was determined according to the colour chart of Kornerup \& Wansher (1978). 


\section{Results}

\section{Correlation between time and some field growth parameters of $G$. resinaceum}

Data in Table $1 \& 2$ and Figures $2 \& 3$ from the 6 replicates of $G$. resinaceum show that on natural substrate, sporocarps of this species which is annual to perennial (Ryvarden 2000, 2004) grow nearly 2 times faster in length than in width from young till mature stage of growth. Figs $2 \&$ 3 show a continuous and steady increase of sporocarp length from the beginning till mature stage of growth, whereas the growth in width appears more slower to almost stagnant from nearly the $5^{\text {th }}$ month (143 days) of growth. All the 6 replicates monitored started producing spore-prints in form of spore dust (Figs 1C-D) between the $5^{\text {th }}$ and $6^{\text {th }}$ month (150 to 180 days) of growth. The computed correlation equations $\mathrm{Y}=1.11+0.225 \mathrm{X}$ for the growth in length, and $\mathrm{Y}=3.1+0.0874 \mathrm{X}$ for the growth in width with their positive correlation coefficients $r=0.998$ and $r=0.98$ (Fig. 3) confirm a positive relationship between time and growth of sporocarp which reaches full maturity at averagely 253 days (about 8 and $1 / 2$ months) old (Table $1 \& 2$, Fig. 3). Our data and field monitoring show that the natural production of spore-prints is maximal at this period and just few weeks later, it starts declining when sporocarps enter into senescence. However, still according to our field observations, most sporocarps of $G$. resinaceum live on their natural substrate (mostly dead wood) for about 10 to 12 months, even though some rare specimens stay alive for more than 12 months (365 days) with however no significant increase in length and width, before naturally ceasing all metabolism and start rotting. Walleyn \& Rammeloo (1994) reported a Ganoderma sporocarp from Cameroon measuring $84 \mathrm{~cm}$ diameter upon collection, a figure which reported to the correlation equation $\mathrm{Y}=1.11+0.225 \mathrm{X}$ (Fig. 3) gives a figure of $\mathrm{X} \approx 368.4$ days corresponding to a little bit more than a full year (12 months) of growth, assuming that the collected specimen was G. resinaceum which is one of the most widespread species in the area of collection in Cameroon. These figures remarkably corroborate our above mentioned field observations on the approximate life span of sporocarps of this species.

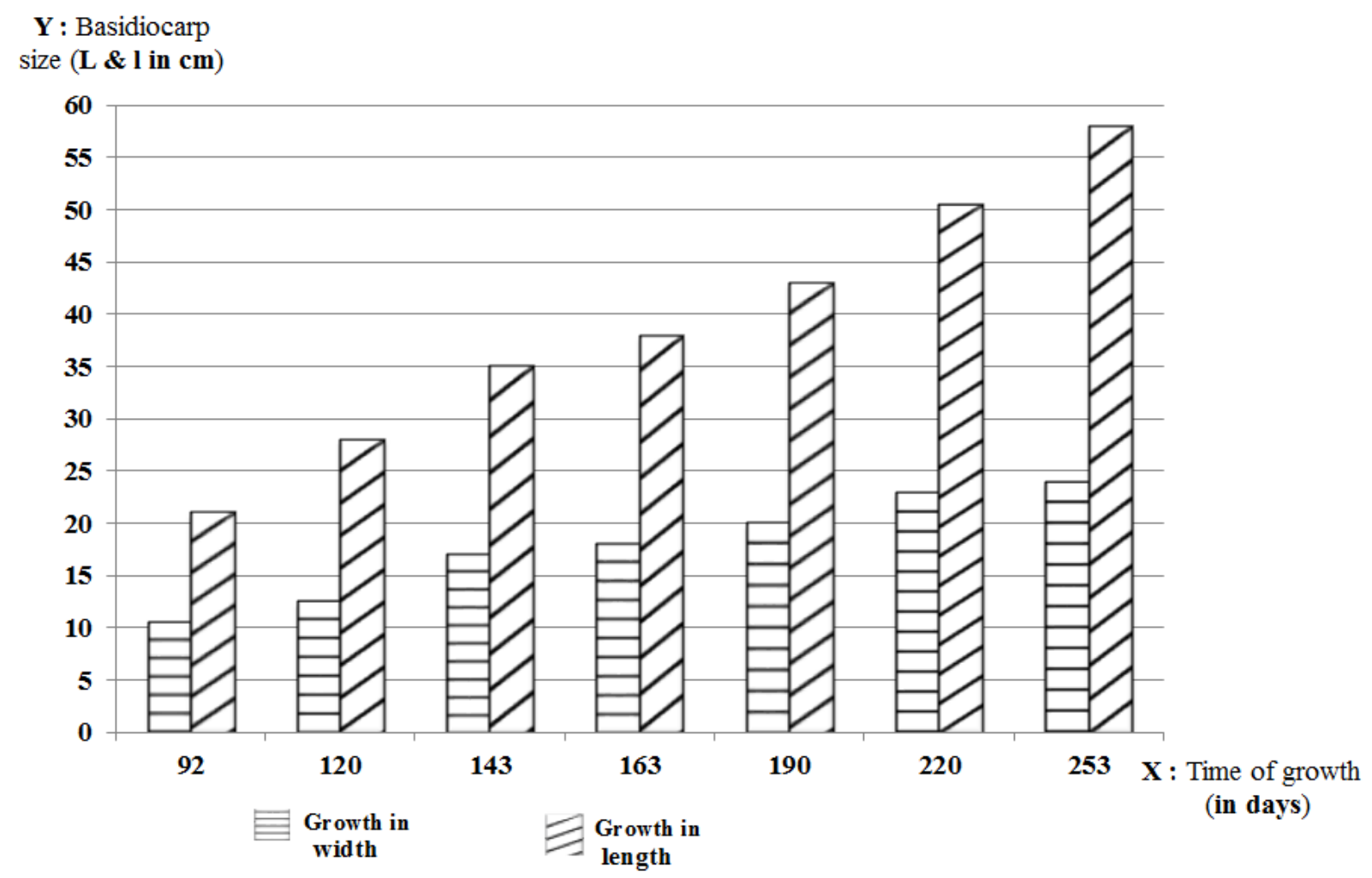

Fig. 2 - Histograms comparing the growth in length and in width of basidiocarps of G. resinaceum on natural substrate 
All in all, considering that the average life span of a sporocarp of $G$. resinaceum is about 10 to 12 months (rarely more) in tropical climates (Table 3) and that sporocarps start producing sporeprints averagely between 5 to 6 months till about 8 to 9 months old as explained above, it is henceforth possible using the equation $\mathrm{Y}=\mathrm{a}+\mathrm{bX}$ and the sporocarps measurements ( $\mathrm{L} \& 1$ as $\mathrm{Y}$ ) on the field, to work out and forecast - for a young sporocarp in active growth (Fig. 1E) on its natural substrate - several important parameters including:

a) the approximate time of growth of sporocarp from its primordium stage till the date its length (L) and width (l) are measured on the field, that is the growth history of the sporocarp in time

b) most importantly and using the data obtained in (a), the approximate best period (time on calendar) to start hunting spore-prints on the field, considering that they most often start appearing conspicuously in form of a chocolate-brown (8F5-7) dust (Figs 1C-D) on the upper side of sporocarps when these are about 5 to 6 months old which is about half the average lifespan of this species

c) the approximate period, as a time range on calendar, when sporocarps senescence will begin considering the above mentioned average life span of this species.

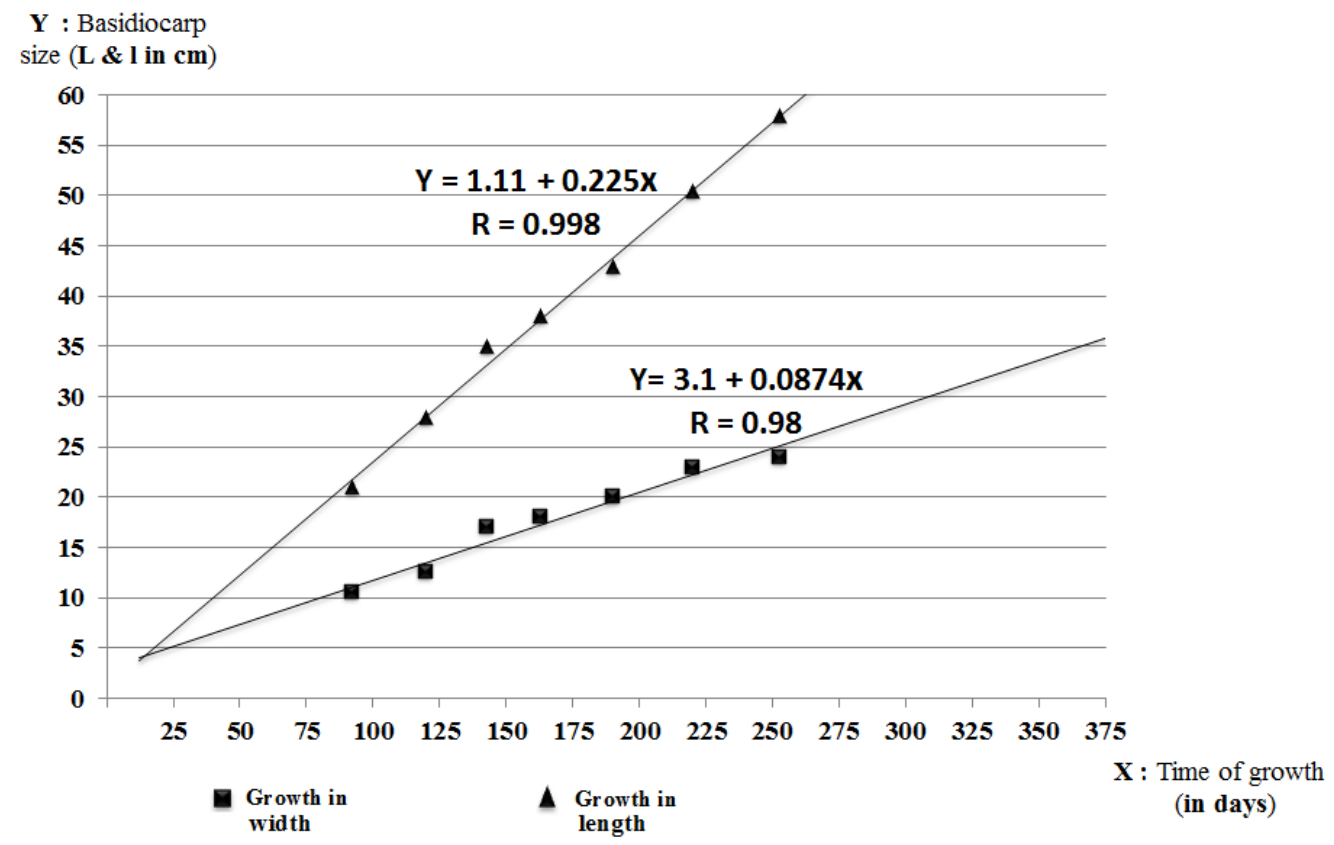

Fig. 3 - Correlation between size (L \& 1) of basidiocarps of G. resinaceum and time of growth in days

\section{Statistical calculations}

Table 1 Statistical data and correlation equation between growth in length (L) and time of sporocarp of Ganoderma resinaceum growing on natural substrate

\begin{tabular}{lllll}
\hline $\begin{array}{l}\mathbf{X} \\
\text { (time in days) }\end{array}$ & $\begin{array}{l}\mathbf{Y} \\
\text { (growth in length) }\end{array}$ & $\mathbf{X}^{\mathbf{2}}$ & $\mathbf{Y}^{\mathbf{2}}$ & $\mathbf{X . Y}$ \\
\hline & & & & \\
92 & 21 & 8464 & 441 & 1932 \\
120 & 28 & 14400 & 784 & 3360 \\
143 & 35 & 20449 & 1225 & 5005 \\
163 & 38 & 26569 & 1444 & 6194 \\
190 & 43 & 36100 & 1849 & 8170 \\
220 & 50,5 & 48400 & 2550,25 & 11110 \\
253 & 58 & 64009 & 3364 & 14674 \\
\hline
\end{tabular}

Each value of $\mathrm{X}$ and $\mathrm{Y}$ represents the mean of 6 replicates (6 different sporocarps monitored at different sites) 
$\mathbf{n}=7$

$\sum x=1181 ; \quad \sum x^{2}=218391 ; \quad\left(\sum x\right)^{2}=1394761$

$\sum Y=273.5 ; \quad \sum Y^{2}=11657.25 ; \quad\left(\sum Y\right)^{2}=74802.25$

$\sum X \cdot Y=50445$

\section{Means of $\mathrm{X}$ and $\mathrm{Y}$ from Table 1:}

$\bar{X}=\frac{\sum \mathrm{X}}{\mathrm{n}}=\frac{1181}{7}=168.71$ et $\bar{Y}=\frac{\sum \mathrm{Y}}{\mathrm{n}}=\frac{273.5}{7}=39.07$

Coefficient a and $b$ of the regression line $(Y=a+b X)$ for the growth in length:

$$
\begin{gathered}
\mathbf{b}=\frac{\sum X \cdot Y-\frac{\sum X \cdot \sum Y}{n}}{\sum X^{2}-\frac{\left(\sum X\right)^{2}}{n}}=\frac{50445-\frac{1181 x 273.5}{7}}{218391-\frac{1394761}{7}}=0.225 \\
\mathbf{a}=\bar{Y}-b \bar{X}=39.07-0.225 \times 168.71=1.11 \\
Y=1.11+0.225 X
\end{gathered}
$$

\section{Correlation coefficient (r):}

$$
\begin{aligned}
& \mathbf{r}=\frac{\sum X \cdot Y-\frac{\sum X \cdot \sum Y}{n}}{\sqrt{\left[\sum X^{2}-\frac{\left(\sum X\right)^{2}}{n}\right] x\left[\sum Y^{2}-\frac{\left(\sum Y\right)^{2}}{n}\right]}} \\
& \mathbf{r}=\frac{50445-\frac{1181 \times 273.5}{7}}{\sqrt{\left[218391-\frac{1394761}{7}\right] \times\left[11657.25-\frac{74802.25}{7}\right]}}=0.998 \\
& \mathbf{r}=\mathbf{0 . 9 9 8}
\end{aligned}
$$

Table 2 Statistical data and correlation equation between growth in width (1) and time of sporocarp of Ganoderma resinaceum growing on natural substrate

\begin{tabular}{lllll}
\hline $\begin{array}{l}\mathbf{X} \\
\text { (time in days) }\end{array}$ & $\begin{array}{l}\mathbf{Y} \\
\text { (growth in width) }\end{array}$ & $\mathbf{X}^{\mathbf{2}}$ & $\mathbf{Y}^{\mathbf{2}}$ & $\mathbf{X . Y}$ \\
\hline & & & & \\
92 & 10,5 & 8464 & 110,25 & 966 \\
120 & 12,5 & 14400 & 156,25 & 1500 \\
143 & 17 & 20449 & 289 & 2431 \\
163 & 18 & 26569 & 324 & 2934 \\
190 & 20 & 36100 & 400 & 3800 \\
220 & 23 & 48400 & 529 & 5060 \\
253 & 24 & 64009 & 576 & 6072 \\
\hline
\end{tabular}

Each value of $\mathrm{X}$ and $\mathrm{Y}$ represents the mean of 6 replicates (6 different sporocarps monitored at different sites)

$$
\begin{aligned}
& \mathbf{n = 7}=1181 ; \quad \sum \mathrm{X}^{2}=218391 ; \quad\left(\sum \mathrm{X}\right)^{2}=1394761 \\
& \sum \mathrm{Y}=125 ; \quad \sum \mathrm{Y}^{2}=2384.50 ; \quad\left(\sum \mathrm{Y}\right)^{2}=15625 \\
& \sum \mathrm{X} \cdot \mathrm{Y}=22763
\end{aligned}
$$


Means of $X$ and $Y$ from Table 2:

$$
\bar{X}=\frac{\sum \mathrm{X}}{\mathrm{n}}=\frac{1181}{7}=168.71 \text { et } \bar{Y}=\frac{\sum \mathrm{Y}}{\mathrm{n}}=\frac{125}{7}=17.86
$$

Coefficients a and $b$ of the regression line $(Y=a+b X)$ for the growth in width:

$$
\begin{gathered}
\mathbf{b}=\frac{\sum X \cdot Y-\frac{\sum X \cdot \sum Y}{n}}{\sum X^{2}-\frac{\left(\sum X\right)^{2}}{n}}=\frac{22763-\frac{1181 \times 125}{7}}{218391-\frac{1394761}{7}}=0.087 \\
\mathbf{a}=\bar{Y}-b \bar{X}=17.86-0.0874 \times 168.71=3.1 \\
\mathbf{Y}=\mathbf{3 . 1}+\mathbf{0 . 0 8 7 X}
\end{gathered}
$$

Correlation coefficient $(r)$ for the growth in width:

$$
\begin{gathered}
\mathbf{r}=\frac{\sum X \cdot Y-\frac{\sum X \cdot \sum Y}{n}}{\sqrt{\left[\sum X^{2}-\frac{\left(\sum X\right)^{2}}{n}\right] x\left[\sum Y^{2}-\frac{\left(\sum Y\right)^{2}}{n}\right]}} \\
\mathbf{r}=\frac{22763-\frac{1181 \times 125}{7}}{\sqrt{\left[218391-\frac{1394761}{7}\right] \times\left[2384.5-\frac{15625}{7}\right]}}=0.98 \\
\mathbf{r}=\mathbf{0 . 9 8}
\end{gathered}
$$

\section{Discussion and conclusion}

Having set for the first time the correlation equation $\mathrm{Y}=\mathrm{a}+\mathrm{bX}$ in order to estimate or anticipate parameters such as time of growth, life span and optimal period of collection of sporeprints on actively growing sporocarps of $G$. resinaceum on the field, this equation could be considered as a major progress in field mycology, since it henceforth enables to collect these sporeprints at the right time on mature sporocarps spotted before on the field just at their primordium or very young stage of growth.

The equation obtained here $(\mathrm{Y}=1.11+0.225 \mathrm{X}$ for the growth in length, and $\mathrm{Y}=3.1+0.0874 \mathrm{X}$ for the growth in width) with our field data in the growth conditions (Table 3) indicated, could be considered as a model applicable in most tropical parts of the world with comparable climates and this model could be used to work out other equations from data recorded in totally different conditions of growth. In fact, considering that $G$. resinaceum is a cosmopolitan species growing as well in tropical as in temperate climates, a correlation equation $(\mathrm{Y}=\mathrm{a}+\mathrm{bX})$ could be worked out by monitoring sporocarps evolving in the northern hemisphere with relatively cold climates, and this will enable to assess whether these correlation equations are comparable and could apply in any part of the world, no matter the climate conditions in which the sporocarp grows.

As far as mycological studies including investigations or cultures of isolated single or multispores of Ganoderma in general and G. resinaceum in particular are concerned, the correlation equation could be considered as a major progress since it henceforth enables to avoid misjudgements of the real stage of growth and presumed period of spore-prints production by sporocarps on natural substrate. Using this correlation equation now offers the possibility of collecting these spore-prints at the right time on the field since sporocarps of this species and most other Ganoderma cease to produce spore-prints once they are collected from their natural substrate.

Data recorded on field show that when growing on dead wood (Table 3) which is their most suitable substrate, sporocarps of G. resinaceum of the same age or so, generally show no significant difference, neither in their size and other external features in direct relationship with the substrate species, nor in the quantity, density and regularity in the production of spore-prints.

Also, field observations show that climatic parameters such as rains, wind etc. had no significant effect on monitoring the optimal period of spore-prints production, since once the 
Table 3 Geographical coordinates and climatic parameters of growth of the 6 replicates (6 sporocarps) of Ganoderma resinaceum monitored to compute the correlation equation

\begin{tabular}{|c|c|c|c|c|c|c|}
\hline $\begin{array}{l}\text { Replicate } \\
\text { number }\end{array}$ & $\begin{array}{l}\text { Herbarium } \\
\text { number of } \\
\text { sporocarps } \\
\text { monitored on } \\
\text { the field }\end{array}$ & $\begin{array}{l}\text { Period of } \\
\text { start and end } \\
\text { of sporocarps } \\
\text { monitoring }\end{array}$ & $\begin{array}{l}\text { Growth area of sporocarps } \\
\text { monitored }\end{array}$ & $\begin{array}{l}\text { GPS coordinates } \\
\text { of the growth area }\end{array}$ & $\begin{array}{l}\text { Substrate (mostly } \\
\text { dead wood) }\end{array}$ & $\begin{array}{l}\text { Some geographical and } \\
\text { climatic parameters of the } \\
\text { growth and monitoring } \\
\text { area of sporocarps }\end{array}$ \\
\hline 1 & $\begin{array}{l}\text { HUY1- } \\
\text { DM } 887\end{array}$ & $\begin{array}{l}\text { Nov. } 2012 \text { to } \\
\text { Oct. } 2013\end{array}$ & $\begin{array}{l}\text { Campus of the University of } \\
\text { Yaoundé1/Cameroon }\end{array}$ & $\begin{array}{l}\mathrm{N} 03^{\circ} 51^{\prime} 31,6^{\prime \prime} \\
\mathrm{E} 11^{\circ} 29^{\prime} 59^{\prime \prime}\end{array}$ & $\begin{array}{l}\text { Stump } \\
\text { angiosperm }\end{array}$ & $\begin{array}{l}\text { Average } \quad \text { yearly } \\
\text { temperature: } \mathbf{2 4 . 7 2}^{\circ} \mathbf{C} \text {. }\end{array}$ \\
\hline 2 & $\begin{array}{l}\text { HUY1- } \\
\text { DM } 888\end{array}$ & $\begin{array}{l}\text { Nov. } 2012 \text { to } \\
\text { Oct. } 2013\end{array}$ & Yaoundé/Cameroon & $\begin{array}{l}\mathrm{N} 03^{\circ} 52^{\prime} 21^{\prime \prime} \\
\mathrm{E} 11^{\circ} 31^{\prime} 03^{\prime \prime}\end{array}$ & $\begin{array}{l}\begin{array}{l}\text { Stump of oil palm } \\
\text { tree } \\
\text { guineensis) }\end{array} \\
\end{array}$ & $\begin{array}{l}\text { - Average annual rainfall: } \\
\mathbf{1 5 3 7 . 2} \mathbf{~ m m} \text {. } \\
\text { - Average monthly }\end{array}$ \\
\hline 3 & $\begin{array}{l}\text { HUY1- } \\
\text { DM } 889\end{array}$ & $\begin{array}{l}\text { Nov. } 2012 \text { to } \\
\text { Oct. } 2013\end{array}$ & Yaoundé/Cameroon & $\begin{array}{l}\mathrm{N} 03^{\circ} 51^{\prime} 38^{\prime \prime} \\
\mathrm{E} 11^{\circ} 30^{\prime} 07^{\prime \prime}\end{array}$ & $\begin{array}{ll}\begin{array}{l}\text { Stump } \\
\text { angiosperm }\end{array} & \text { of } \\
\end{array}$ & $\begin{array}{l}\text { rainfall: } \mathbf{1 2 8 . 1} \mathbf{~ m m} \text {. } \\
\text { - Average yearly air }\end{array}$ \\
\hline 4 & $\begin{array}{l}\text { HUY1- } \\
\text { DM } 890\end{array}$ & $\begin{array}{l}\text { Nov. } 2012 \text { to } \\
\text { Oct. } 2013\end{array}$ & Yaoundé/Cameroon & $\begin{array}{l}\mathrm{N} 03^{\circ} 52^{\prime}, 28^{\prime \prime} \\
\mathrm{E} 11^{\circ} 31^{\prime} 04^{\prime \prime}\end{array}$ & $\begin{array}{l}\text { Stump of oil palm } \\
\text { tree } \\
\text { guineensis) }\end{array}$ & $\begin{array}{l}\text { moisture: } \mathbf{R H}=\mathbf{7 7 . 1 \%} \\
\text { - } \quad \text { Average altitude: } \mathbf{7 5 0} \mathbf{m}\end{array}$ \\
\hline 5 & $\begin{array}{l}\text { HUY1- } \\
\text { DM } 891\end{array}$ & $\begin{array}{l}\text { Nov. } 2012 \text { to } \\
\text { Oct. } 2013\end{array}$ & Yaoundé/Cameroon & $\begin{array}{l}\mathrm{N} 03^{\circ} 51^{\prime} 33^{\prime \prime} \\
\mathrm{E} 11^{\circ} 31^{\prime} 02^{\prime \prime}\end{array}$ & Tree trunk & - Photoperiodicity: \\
\hline 6 & $\begin{array}{l}\text { HUY1- } \\
\text { DM } 892\end{array}$ & $\begin{array}{l}\text { Nov. } 2012 \text { to } \\
\text { Oct. } 2013\end{array}$ & Yaoundé/Cameroon & $\begin{array}{l}\text { N } 03^{\circ} 52^{\prime} 26^{\prime \prime} \\
\text { E } 11^{\circ} 32^{\prime} 06\end{array}$ & $\begin{array}{l}\text { Stump } \\
\text { angiosperm }\end{array}$ & $\begin{array}{l}\text { about equally } 12 \text { hours } \\
\text { of daylight and } 12 \text { hours } \\
\text { of darkness over the } 12 \\
\text { months of the year. }\end{array}$ \\
\hline
\end{tabular}

sporocarps of G. resinaceum have reached maturity, they start producing spore-prints continuously and mostly overnight, so that even just few hours or days after a rainfall, new dust of spore-prints appears on the pileus.

About the status of Ganoderma species in general which are said to be annual to perennial according to several authors (Ryvarden \& Johansen 1980; Breitenbach \& Kränzlin 1986, Giltbertson and Ryvarden 1986; Ryvarden \& Giltbertson 1993; Ryvarden 2000, 2004), and as far as G. resinaceum is concerned, we can here affirm on the basis of our field observations (Mossebo et al. 2014a, Mossebo \& Ayissi 2014b) over several years on numerous specimens of this species and also the sporocarps specially monitored in the framework of this study, that in tropical conditions (Table 3), sporocarps of G. resinaceum tend to be more annual than perennial, except for some rare specimens found underwood under the wide canopy of the green tropical forest where they undoubtedly benefit from cooler biotopes and lower temperatures that preserve them better and for longer periods and this explains why perennial specimens are found much more in cold climates of the northern hemisphere. Otherwise, most sporocarps of G. resinaceum monitored in savannahs or in urban areas and growing in tropical conditions close to those mentioned earlier (Table 3) rarely exceed a life span of 10 to 12 months as mentioned in our results, this presumably due to heat, high temperatures and high air moisture that do not at all favour conservation for long periods of time, but rather favour development of various types of moulds and insects which contribute to a much more rapid deterioration of sporocarps on their natural substrate and thereby reduce their life span and potential period of collection of spore-prints on the field in tropical conditions. 


\section{Acknowledgments}

The authors are very grateful to emeritus Professor Leif Ryvarden of the University of Oslo in Norway for cross-checking our preliminary identifications of Ganoderma resinaceum specimens monitored on the field in order to compute the correlation equation. The authors specially thank Vivien Onka Mouanda, Statistics Engineer at the Sub-Regional Institute of Statistics and Applied Economics (ISSEA) for central Africa in Yaoundé, Cameroon, for assisting us in computing the correlation equations. We are also grateful to the Cameroon Ministry of Higher Education (MINESUP) for the special support fund for research and the grant $\mathrm{N}^{\circ} 16-00433 / \mathrm{MINESUP} / \mathrm{SG} / \mathrm{CS}$ thanks to which part of the field work was carried out.

\section{References}

Adaskaveg JE, Giltbertson R, 1986 - Cultural studies and genetics of sexuality of Ganoderma lucidum and G. tsugae in relation to the taxonomy of the G. lucidum complex. Mycologia 78, 694-705.

Boudier EJL, 1889 - Etude descriptive d'une nouvelle espèce de Ganoderma de France: Ganoderma resinaceum sp.nov. Bulletin de la Société mycologique de France 5, 72.

Breitenbach J, Kränzlin F, 1986 - Les Champignons de Suisse. Tome 2. Champignons à lames. Hétérobasidiomycètes, Aphyllophorales, Gastéromycètes. Edition Mycologia, CH-6000, Luzerne 9. 412 p.

Bresadola J, 1890 - Fungi kamerunenses. Bulletin de la Société Mycologique de France. 6, XXXII-XLIX.

Chang ST, Buswell JA, 1999 - Ganoderma lucidum (Curt.; Fr.) P. Karst. (Aphyllophoromycetideae). A mushrooming medicinal mushroom. International Journal of Medicinal Mushrooms 1, 139-146.

Furtardo JS, 1967 - Some tropical species of Ganoderma (Polyporaceae) with pale context. Persoonia 4, 379-389.

Furtardo JS, 1965 - Relation of microstructure to the taxonomy of the Ganodermataceae (Polyporaceae) with special reference to the structure of the cover of the pilear surface. Mycologia 57, 688-711.

Giltbertson RL, Ryvarden L, 1986 - North American Polypores. Volume 1. Fungiflora, Oslo, Norway. $433 \mathrm{p}$.

Hjortstam K, Ryvarden L, Watling R, 1993 - Preliminary checklist of non-agaricoid macromycetes in the Korup National Park, Cameroon and surrounding area. Edinburg Journal of Botany 50 (1), 105-119.

Kinge TR, 2012 - Basal Stem Rot Disease of Oil palm and Identification of species of Ganoderma in South Western Cameroon. Ph.D thesis, University of Buea, Cameroon. 272 p.

Kinge TR, Mih A, 2011 - Ganoderma ryvardense sp. nov. associated with basal stem rot (BSR) disease of oil palm in Cameroon. Mycosphere 2(2), 179-188.

Kornerup A, Wansher JH, 1978 - Methuen handbook of colour. $3^{\text {rd }}$ edn. Eyre Methuen, London. $252 \mathrm{p}$.

Ling-Chie Wong, Choon-Fah J Bong, Idriss AS, 2012 - Ganoderma Species Associated with Basal Stem Rot Disease of Oil palm. American Journal of Applied Sciences 9 (6), 879-885.

Mc.Donald JH, 2014 - Handbook of Biological Statistics. $3^{\text {rd }}$ edn. Sparky House Publishing, Baltimore, Maryland.

Moncalvo JM, Ryvarden L, 1997 - A nomenclatural Study of the Ganodermataceae Donk. Synopsis Fungorum 11. Fungiflora-Oslo-Norway. 114 p.

Mossebo DC, Kengni Ayissi MB, Ambit RT, 2014a - New taxa and potential pharmacological properties of some Ganodermataceae (Basidiomycota) from Cameroon and central Africa. In abstracts book (Scripta Botanica Belgica 52, 291) of the Proceedings of the XXth AETFAT Congress, Stellenbosch, South Africa, $13^{\text {th }}-17^{\text {th }}$ January 2014. 
Mossebo DC, Kengni Ayissi MB, 2014b - Some noteworthy taxonomic variations in the complex wood-decayer Ganoderma resinaceum (Basidiomycota) with reference to collections from tropical Africa. Kew Bulletin 69(4). Doi: 10.1007/s12225-014-9542-9

Mossebo DC, Njouonkou AL, Courtecuisse R, Amougou A, 2007 - Enzymatic activities and decay characteristics in some wood-rotting Basidiomycetes from Cameroon and determination of the time-dependant activity of syringaldazine in spot tests. CryptogamieMycologie 28(2), 107-121.

Mossebo DC, 2005 - Contribution à la connaissance de la flore mycologique tropicale : Inventaire, taxonomie et systématique des collections de Basidiomycètes (Macromycètes) du Cameroun et d'Afrique centrale. Mémoire d'Habilitation à Diriger des Recherches (HDR), Université de Lille 2, France. 127 p.

Mossebo DC, Ryvarden L, 2003 - The Genus Mycorrhaphium in Africa. Mycotaxon 88, 229 -232.

Mossebo DC, 1998 - Etude de la polarité sexuelle chez Dacrymyces stillatus Nees : Fries (Basidiomycète). Cryptogamie-Mycologie. 19(4), 285-300.

Mossebo DC, Ryvarden L, 1997 - Fomitopsis africana sp. nov. (Polyporaceae, Basidiomycotina). Sydowia 49(2), 147-149.

Mossebo DC, 1995 - "Karyologishe Untersuchungen zur sexuellen Fortpflanzung von Dacrymyces stillatus nees ex Fries (Basidiomycetes) und Ultrastruktur der Konidiogenese” . Ph.D Thesis, Universität-Tübingen, Germany. 165 p.

Nŭnez M, Ryvarden L, 2000 - East Asian Polypores. Vol. 1. Ganodermataceae and Hymenochataceae. Synopsis Fungorum 13, Fungiflora (edn.), Blindern, Oslo, Norway. 198 p.

Parker RE, 1991 - Introductory Statistics for Biology. (Studies in Biology), second ed., Cambridge University Press. 122 p.

Roberts P, Ryvarden L, 2006 - Poroid fungi from Korup National Park, Cameroon. Kew Bulletin $61,55-78$.

Ryvarden L, 2004 - Neotropical polypores, Part 1. Introduction, Ganodermataceae \& Hymenochaetaceae. Synopsis Fungorum 19, Fungiflora (edn.), Blindern, Oslo, Norway. 227 p.

Ryvarden L, 2000 - Studies in neotropical polypores 2: A preliminary key to neotropical species of Ganoderma with a laccate pileus. Mycologia 92 (1), 180-191.

Ryvarden L, Giltbertson RL, 1993 - European Polypores part 1. Synopsis Fungorum 6. Fungiflora (edn.), Oslo, Norway. 387 p.

Ryvarden L, 1992 - Genera of Polypores; nomenclature and taxonomy. Synopsis fungorum 5. Fungiflora (ed.), Oslo, Norway. 292 p.

Ryvarden L, Johansen I, 1980 - A Preliminary Polypore Flora of East Africa, Fungiflora (ed.), Oslo. $636 \mathrm{p}$.

Steyaert RL, 1980 - Study of some Ganoderma species. Bulletin du Jardin Botanique Nationale Belgique 50, 135--186.

Steyaert RL, 1972 - Species of Ganoderma and related Genera, mainly of the Bogor and Leiden Herbaria. Persoonia 7, 55-118.

Steyaert RL, 1967 - Les Ganoderma palmicoles. Bulletin du Jardin Botanique Nationale Belgique 37 (4), 465-492.

Steyaert RL, 1962 - Genus Ganoderma (Polyporaceae). Taxa Nova II. Bulletin du Jardin Botanique Nationale Belgique 32, 89-104..

Walleyn R, Rammeloo J, 1994 - The poisonous and useful fungi of Africa South of Sahara: A literature survey. National Botanic Garden of Belgium, Meise. Scripta Botanica Belgica. Volume 10, 1-56.

Zoberi MH, 1972 - Tropical macrofungi. Some common species. The MacMillan Press Ltd, London and Basingstoke. 158 p. 